University of Wollongong

Research Online

University of Wollongong in Dubai - Papers

University of Wollongong in Dubai

$1-1-2009$

\title{
Facebook usage among Arabic college students: preliminary findings on gender differences
}

Kathy Ning Shen

University of Wollongong in Dubai, kathys@uow.edu.au

Mohamed Khalifa

University of Wollongong in Dubai, mkhalifa@uow.edu.au

Follow this and additional works at: https://ro.uow.edu.au/dubaipapers

\section{Recommended Citation}

Shen, Kathy Ning and Khalifa, Mohamed: Facebook usage among Arabic college students: preliminary findings on gender differences 2009, 1080-1087.

https://ro.uow.edu.au/dubaipapers/43

Research Online is the open access institutional repository for the University of Wollongong. For further information contact the UOW Library: research-pubs@uow.edu.au 


\title{
FACEBOOK USAGE AMONG ARABIC COLLEGE STUDENTS: PRELIMINARY FINDINGS ON GENDER DIFFERENCES
}

\author{
Kathy Ning Shen ${ }^{1}$ and Mohamed Khalifa ${ }^{2}$ \\ Faculty of Business and Management \\ University of Wollongong in Dubai, United Arab Emirates \\ 1athyshen@uowdubai.ac.ae; ${ }^{2}$ mohamedkhalifa@uowdubai.ac.ae
}

\begin{abstract}
With immense popularity and candid participation, Facebook shows a greater potential in developing customer communities, promoting online presence, advertising, and customizing services/products. Despite its popularity, research on Facebook in particular and social networking sites in general is far behind the practice. Particularly, research outside the western countries is very limited. With the young generation of Arabic world embarking on Internet, social networking sites, e.g., Facebook, have been used as a main arena for their identity construction, and relationship development, playing a vital role in shaping future society. Thus, the purpose of this study is to provide descriptive information about the use of Facebook by Arabic college students with a focus on gender differences in motivations and perceived consequences of Facebook usage.
\end{abstract}

Keywords: Social Networking Sites; Adolescents; IT Usage; Trust

\section{Introduction}

According to Boyd and Ellison [1], social networking sites are "web-based services that allow individuals to 1) construct a public or semi-public profile within a bounded system, 2) articulate a list of other users with whom they share a connection, and 3) view and traverse their list of connections and those made by others within the system." In the past couple of years alone, social networking sites such as Frienderster, MySpace, and Facebook have become immensely popular among adolescents and emerging adults. Among various social networking sites, Facebook is currently considered as a rich site for researchers interested in social networks due to its heavy usage patterns and technological capacities that bridge online and offline connections. Particularly as the statistics by Jan. 2009i, Facebook, originally created for college students, has attracted more than 150 million active users with more than half of them are outside of college. The fastest growing demographic is those 30 years old and older. Facebook has become an integral part of daily life. On average, each user has 100 friends on the site, spends more than 3 billion minutes on Facebook each day (worldwide). More than 13 million users update their statuses at least once each day and more than 3 million users track certain pages on a daily base. More than that, Facebook is also increasingly leveraged by politicians, protesters, social activists, companies and etc. to achieve a wide range of objectives. A good example is Obama's campaign in 2008.

Compared to traditional online communities, the strict policy enforced in Facebook against the use of pseudonyms help cultivate a culture of honesty that is not always found in other online communities. With immense popularity and candid participation, Facebook shows a greater potential in developing customer communities, promoting online presence, advertising, and customizing services/products. For instance, several libraries have setup their Facebook profile to provide customize the service for college students. Facebook is also embarking e-commerce by partnering with Amazon.com. Although many business models are still in the experimental stage, no one would ignore Facebook's potential in e-commerce.

Despite its popularity, research on Facebook in particular and social networking sites in general is far behind the practice. Particularly, research outside the western countries is almost empty. With the young generation of Arabic world embarking on Internet, social networking sites, e.g., Facebook, have been used as a main arena for their identity construction, and relationship development, playing a vital role in shaping future society [2]. For instance, Ayed [3], in his field study, demonstrated that Internet plays an important role in shaping the political attitudes and culture among the youth. The young generation in the Arab world are influenced by both Islamic and modern cultures [4], which may not stay in harmony. Therefore, it is important to gain the insights on how the young generation interacts with social networking sites in general and Facebook in particular. Moreover, prior research has observed that, despite opportunities of hiding identities online [5], users' online behavior is still subject to their offline identities [6]. Research on refined understandings of the digital divide has found that equal access to Internet resources does not guarantee homogeneity among users' online pursuits [7, 8]. Among various offline identities, gender has been demonstrated to influence a wide array of user-technology interaction [9, 10]. Given strong cultural notions of gender in Arabic world, there is 
no reason to assume equal adoption, pursuit and perception of social networking sites between the male and female users. Thus, the purpose of this study is to provide descriptive information about the use of Facebook by Arabic college students with a focus on gender differences in motivations and perceived consequences of Facebook usage. Crucial questions for understanding the use of such applications address self-perception in Facebook, frequent activates, influential others in Facebook adoption, perceived trust and perceived consequences of using Facebook.

\section{Internet Usage and Facebook Adoption in UAE}

The Internet is a global phenomenon, but with distinct regional profile [11]. As indicated in prior research (e.g., Straub et al., 2001), culture and social norms play an important role in shaping Internet usage. We choose The United Arab Emirates (UAE) as our research site due to its relatively high Internet penetration among Middle East countries. UAE was established in 1971 as a federation of seven emirates ii . Within 30 years, this country has undergone significant social, economic, and cultural changes. ETISALAT has been providing Internet services to UAE since August 1995. The country now has one of the highest rates of Internet usage in the Middle East and its telecommunications sector is the most highly developed in the region. According to Emirates Internet and Multimedia (EMI) ${ }^{\mathrm{iii}}$, there are 2.3 million Internet users by March 2008, accounting for $49.8 \%$ of the total population. Nowadays the Internet has become an integral part of life for the young generation in UAE. The penetration of Internet also brings massive opportunities for electronic commerce. A new Arab Advisors Group major survey of Internet users in UAE reveals that 51.2 per cent of Internet users in UAE reported purchasing products and services online and through their mobile handsets in 2007. Particularly, Facebook has become very popular among young people in UAE. Although the exact statistics is missing, its popularity is signaled through some discussions about Facebook in various venues, and recent event of "Blocking Facebook" in UAE. The author's casual survey with students in the classroom also reported about $60 \%$ of Facebook adoption.

Meanwhile, UAE has promoted the gender empowerment by encouraging women to receive education, and take an active part in economic and political life. According to UN reportiv, UAE ranks 24th out of 108 countries in the gender empowerment measure, with a value of 0.698 . This also indicates that compared to other Arabic countries, UAE offers more opportunities for women to access Internet resources. All evidence indicates that Facebook has emerged to be a significant social phenomenon worth much attention in UAE.

UAE nationals, being the minority (15-20\%) in their own country, have kept firm ties to their cultural tradition. Particularly to our interest are those traditions or social norms enforced to the female. Although recently the government encourages Emirate females to join the workforce and take leadership roles in running the country, strong social norms remains applicable for the female. For instance, a female cannot show her face except to close family members, a female is not allowed to interact with others, particularly male, without permission from her family, and a female is not allowed to touch or be touched by males (e.g., a handshake with a work colleague is not permitted). Hence, using Facebook creates a great controversy with respect to the traditional Islamic/Arabic culture, since Facebook empowers the female with more possibilities in extending their social network, and provides more sources for identity exploration and development. Saudi preacher Ali al-Maliki, a leading critic of Facebook, claims the network is corrupting the youth of the nation, "Facebook is a door to lust, and young women and men are spending more on their mobile phones and the Internet than they are spending on food." $v$ The conflict brought by the usage of Facebook and exposure to western culture, is expected to be stronger among women than men in UAE, which implies significant gender differences in Facebook usage and perception.

How do people perceive themselves in Facebook? According to Erikson [12], identity is the main developmental task of adolescence. Research in developmental psychology has demonstrated that as Internet becomes a main social environment for most people, it becomes an essential arena for identity experimentation and exploration, playing an important role in adolescent development [13]. Same theories are also applicable to Arab youth. For instance, Ayed [3], in his field study, demonstrated that Internet plays an important role in shaping the political attitudes and culture among the youth. The young generation in the Arab world are influenced by both Islamic and modern cultures [4], which may not stay in harmony. The conflict brought by the usage of Internet and exposure to western culture, fundamentally shapes the self-perception of young generation and understanding of their self-perception in Facebook would be the first step.

\section{What do they do with Facebook?}

Facebook was originally designed to be a social networking site for connecting college students, but now extends to high schools and other organizations. When people join Facebook, they start by creating a 
profile which can be used to identify connections to those who share the similar characteristics. Members can also connect to those they meet through the site. Built upon this basic networking function is the rich communication and relationships among members, fulfilling a number of purposes. Despite equal access to Facebook, different users may have their own online pursuits [7, 8]. Particularly, we are interesting in gender differences in Facebook activities. Since women are subject to more limitations in physical life than men, Facebook, providing an alternative online playground, may be perceived to be more important among women than men. Therefore, in this study, we try to provide some preliminary results regarding the specific pursuits for Facebook among Arabic young students, and gender differences in Facebook activities.

\section{Who are the most influential others for Facebook usage?}

According to theory of planned behavior [14], one of the determinants of behavior intention is subjective norms, defined as "a person's perception that most people who are important to him think he should or should not perform the behavior in question”. Such perceived pressure from important others exerts its influences through three major mechanisms: compliance, internalization and identification [15]. Compliance means the person is motivated by the need for approval from significant others. Internalization refers to the adoption of a decision based on the congruence of one's values with the values of another. Identification suggests that the person defines him/herself in terms of features of social category that renders the self stereotypically "interchangeable" with other group members, and stereotypically distinct from outsiders [16]. Subjective norms are particularly relevant in understanding Arab students' Facebook usage due to the fact that the traditional Islamic values remain influential, especially for female students. The initial attempt in this study would be identification of important others, and gender differences in social influences.

\section{Do they trust people in Facebook?}

Trust deals typically with beliefs regarding the ability, benevolence, and integrity of the trusted party [17]. As a central concept in social exchange, trust helps reduce uncertainty, enhance predictability, and alleviate complexity in social interaction [18] and human-computer interaction [19]. Existing evidence also demonstrates that trust is one of major factors for sustaining virtual communities [20], guaranteeing the successful IT adoption [19], enhancing business-to-business [21] and business-to-consumer electronic commerce [22]. Particularly for people interacting in Facebook, trust may affect their information disclosure and willingness to enter and carry on relationships with the others [23]. Therefore, in this study, we are interested in trust in the other social actors in Facebook.

\section{What are the perceived consequences of using Facebook?}

Perceived consequences are derived from Triandis' model [24]. According to this model, each act or behavior is perceived as having a potential outcome that can be either positive or negative. An individual's choice of behavior is based on the probability that an action will provoke a specific consequence. Identifying the consequences of using Facebook would shed lights on the determinants of Facebook usage.

\section{Method}

In order to understand the gender differences in Facebook usage among UAE college students, a survey was conducted in a private university in UAE during the Spring 2008 semester. In the survey, we mainly focused on the following subjects, i.e., self-perception in Facebook, frequent activates, influential others in Facebook adoption, perceived trust and perceived consequences of using Facebook. While adopting scales validated in prior research, e.g., trust [25], subjective norms [26], prior to the survey, we also organized a focus group discussion with 20 students who did not attend the survey study in order to identify the measures for frequent activities with Facebook, perceived consequences, and influential others in measuring subjective norms. For instance, many students expressed their concern about the negative impacts of Facebook on their family relationship and culture, which was later articulated into the survey.

The survey was distributed to 128 students taught by one of the authors and a total of 70 students returned the valid response, with 35 female and 35 male. Participation was completely voluntary without any motivation. Table 1 summarizes the demographic information of the participants. The majority of participants are undergraduate students ranging between 19-30 years old. The distribution of the nationality was consistent with the general ethical distribution in this university. Despite the diversity, almost all students are Muslims and comply with the traditional Islamic culture. A subsequent test indicated insignificant national difference.

More than half of participants had more than 5 years' experience with Internet, which confirmed that using Internet has become their daily routine. More particularly, $84.3 \%$ of participants had at least 6 months' experience with Facebook and $54.3 \%$ of them logged in on a daily base. Consistent with our early survey results, Facebook was very 
popular among young generation of UAE. Moreover, ANOVA test did not report a significant gender difference in the experience with Internet and Facebook, and frequency of Facebook usage. This may suggest that both female and male enjoy similar Internet access.

Table 1: Demographic Information

\begin{tabular}{|l|l|}
\hline Age & Count (\%) \\
\hline $19-30$ & $65(92.9 \%)$ \\
\hline $31-45$ & $5(7.1 \%)$ \\
\hline Frequency of Login & Count (\%) \\
\hline Daily & $38(54.3 \%)$ \\
\hline Weekly & $17(24.3 \%)$ \\
\hline Monthly & $15(21.4 \%)$ \\
\hline Experience with Internet & Count (\%) \\
\hline$>5$ years & $40(57.1 \%)$ \\
\hline $2-5$ years & $26(37.1)$ \\
\hline$<1$ year & $4(5.7 \%)$ \\
\hline Experience with Facebook & Count (\%) \\
\hline$>12$ months & $37(52.9 \%)$ \\
\hline $6-12$ months & $22(31.4 \%)$ \\
\hline$<6$ months & $11(15.7 \%)$ \\
\hline Membership with Facebook & Count (\%) \\
\hline$<6$ months & $18(25.7 \%)$ \\
\hline $6-12$ months & $20(28.6 \%)$ \\
\hline $1-2$ years & $23(32.9 \%)$ \\
\hline $2-5$ years & $9(12.9 \%)$ \\
\hline Nationality & Count (\%) \\
\hline Syrian & $15(21.4 \%)$ \\
\hline UAE & $17(24.2 \%)$ \\
\hline Palestinian & $11(15.7 \%)$ \\
\hline Egyptian & $7(10 \%)$ \\
\hline Indian & $7(10 \%)$ \\
\hline Lebanese & $7(10 \%)$ \\
\hline Pakistani & $6(8.6 \%)$ \\
\hline Education & Count (\%) \\
\hline Undergraduate & $61(87.1 \%)$ \\
\hline Masters & $912.9 \%)$ \\
\hline
\end{tabular}

\section{Data Analysis and Results}

ANOVA was conducted to examine the gender difference in terms of purposes of self-perception in Facebook, frequent activities with Facebook, subjective norm, perceived trust, and perceived consequences of using Facebook.

\section{Self-perception in Facebook}

A key task in adolescent development is the formation of identity. How do people in Facebook perceive themselves? In this survey, we tapped three self-perceptions, i.e., sociable-unsociable, conservative-outgoing; independent-dependent. Selection of these items was based on the gender stereotype in UAE. As one respondent put, "As a UAE guy, I find something that doesn't meet our cultural or religion morale. For instance, a girl can come to me account and say how sexy I am. This is not allowed in our culture." Table 2 reports the gender difference in self-perception in Facebook. Different from the general stereotype, both female and male students reported similar level of sociability and conservativeness, higher than what has been perceived in the physical life. Moreover, although both groups reported a relatively high level of independence, significant difference was found between the female and male students. It seems that the female students who live in Facebook feel more independent. However, this explanation warrants further examination as it might be the result of selection bias.

Table 2: Gender Differences in Self-perception in Facebook

\begin{tabular}{|c|c|c|c|c|}
\hline \multicolumn{2}{|c|}{$\begin{array}{l}\text { ANOVA results: }{ }^{* *}: \mathrm{p}<.01 ; \\
*^{*} \mathrm{p}<.05 \text {; ns: insignificant }\end{array}$} & Mean & Std. & Error \\
\hline \multirow{2}{*}{$\begin{array}{l}\text { In Facebook, I am } \\
\text { very sociable } 1 \text { - } \\
\text { unsociable } 8^{\text {ns }}\end{array}$} & female & 3.31 & 2.529 & .428 \\
\hline & male & 2.77 & 2.079 & .380 \\
\hline \multirow{2}{*}{\begin{tabular}{|l|} 
In Facebook, I am \\
very conservative 1 \\
- outgoing $8^{\text {ns }}$
\end{tabular}} & female & 5.11 & 2.125 & .359 \\
\hline & male & 5.10 & 1.768 & .323 \\
\hline \multirow{2}{*}{\begin{tabular}{|l|} 
In Facebook, I am \\
very dependent 1 - \\
independent $8 *$
\end{tabular}} & female & 6.23 & 2.157 & .365 \\
\hline & male & 5.13 & 1.852 & .338 \\
\hline
\end{tabular}

\section{Frequent Activities with Facebook}

Social networking sites are designed to foster social interaction. Enhanced social network also provides rich information source and fulfill different pursuits of users. Table 3 reports the frequent activities with Facebook identified in focus group discussion, which generally covers most needs of social networking site users, e.g., information needs (Item 1-5), social needs (Item 6-8), entertainment needs (Item 9-10), and development needs (Item 11). The survey results also indicated significant difference in all activities between the male and female students. Specifically, the female students reported more frequency in all activities, indicating that Facebook plays a more important role in the female students' life than their counterpart. 
Table 3: Gender Differences in Frequent Activities with Facebook (1=never; 8=always)

\begin{tabular}{|c|c|c|c|c|}
\hline \multicolumn{2}{|c|}{$\begin{array}{l}\text { ANOVA results: } * *: \mathrm{p}<.01 ; \\
*: \mathrm{p}<.05 \text {; ns: insignificant }\end{array}$} & \multirow{2}{*}{\begin{tabular}{|l} 
Mean \\
4.66
\end{tabular}} & \multirow{2}{*}{\begin{tabular}{|l|} 
Std. \\
2.485
\end{tabular}} & \multirow{2}{*}{$\frac{\text { Error }}{.420}$} \\
\hline \multirow{2}{*}{$\begin{array}{l}\text { 1. To get } \\
\text { information * }\end{array}$} & female & & & \\
\hline & male & 3.43 & 1.814 & .343 \\
\hline \multirow{2}{*}{$\begin{array}{l}\text { 2. To learn how to } \\
\text { do things * }\end{array}$} & female & 4.29 & 2.136 & .361 \\
\hline & male & 3.07 & 2.034 & .378 \\
\hline \multirow{2}{*}{$\begin{array}{l}\text { 3. To provide } \\
\text { others with } \\
\text { information } * *\end{array}$} & female & 6.20 & 2.207 & .373 \\
\hline & male & 3.38 & 2.578 & .506 \\
\hline \multirow{2}{*}{$\begin{array}{l}\text { 4. To generate } \\
\text { ideas ** }\end{array}$} & female & 5.59 & 2.162 & .371 \\
\hline & male & 2.81 & 1.869 & .336 \\
\hline \multirow{2}{*}{$\begin{array}{l}\text { 5. To solve } \\
\text { problems } * *\end{array}$} & female & 4.69 & 2.311 & .391 \\
\hline & male & 2.67 & 2.106 & .385 \\
\hline \multirow{2}{*}{$\begin{array}{l}\text { 6. To seek social } \\
\text { support * }\end{array}$} & female & 5.20 & 2.506 & .424 \\
\hline & male & 3.53 & 2.738 & .500 \\
\hline \multirow{2}{*}{$\begin{array}{l}\text { 7. To meet new } \\
\text { people* }\end{array}$} & female & 5.71 & 2.150 & .363 \\
\hline & male & 4.46 & 1.902 & .373 \\
\hline \multirow{2}{*}{$\begin{array}{l}\text { 8. To socialize } \\
\text { with people similar } \\
\text { to me } *\end{array}$} & female & 6.17 & 1.505 & .254 \\
\hline & male & 5.19 & 2.056 & .369 \\
\hline \multirow{2}{*}{$\begin{array}{l}\text { 9. To be } \\
\text { entertained } * *\end{array}$} & female & 6.91 & 1.704 & .288 \\
\hline & male & 4.29 & 2.209 & .417 \\
\hline \multirow[t]{2}{*}{ 10. To relax ** } & female & 6.20 & 1.937 & .327 \\
\hline & male & 3.00 & 2.181 & .398 \\
\hline \multirow{2}{*}{$\begin{array}{l}\text { 11. To play another } \\
\text { role that I can't in } \\
\text { the real life } * *\end{array}$} & female & 5.80 & 1.279 & .216 \\
\hline & male & 3.19 & 2.937 & .528 \\
\hline
\end{tabular}

First, the female students were reported to be more active in information seeking and contributing activities. Like what one student mentioned in the focus group discussion, "Since I am a woman, I found that it as the only way [online] I could express my opinions and ideas freely." This confirms the claim that Internet in general and Facebook in particular are playing a very important role in empowering women in Arabic world. Secondly, both male and female students consider Facebook as a social venue for networking and seeking social support, although such demands seem more salient among the female students. Thirdly, Facebook is also considered more as a playground for female students than for male students. This may also related to the fact that male students enjoy more freedom and choices for entertainment. Finally, Facebook was found to be an important venue for the female students in experimenting different roles; while such role was not salient among the male students. This result might be related to the difference in enforced limitations between the female and male in the real life. As we mentioned before, despite the economic and social progress, UAE remains close-tied with the Islamic/Arabic traditions, and women are subject to more restrictions. Overall, the usage of Facebook for male students is consistent with its basic function, social networking; while for female students, Facebook seems fulfill various roles and constitutes as an important complement for limitations in their physical social life.

\section{Subjective Norms}

Based on the focus group discussion, we identified four important others in influencing students' decision, i.e., relatives (family members), friends, professors, and classmates. While the peer influence is same across two groups, female students were reported to be more influenced by their relatives and professors than male students. Getting approval from certain authorize seems important for female students' Facebook usage.

Table 4: Gender Difference in Social Norms (1=Strongly Disagree; 8=Strong Agree)

\begin{tabular}{|l|l|l|l|l|}
\hline \multicolumn{2}{|l|}{$\begin{array}{l}\text { ANOVA results: } * * \\
\mathrm{p}<.05 ; \text { ns: insignificant }\end{array}$} & Mean & Std. & Error \\
\hline $\begin{array}{l}\text { My relatives think } \\
\text { that I should use } \\
\text { Facebook } * *\end{array}$ & female & 6.31 & 1.367 & .231 \\
\cline { 2 - 5 } & male & 4.19 & 2.072 & .372 \\
\hline $\begin{array}{l}\text { My friends think that } \\
\text { I should use } \\
\text { Facebook }\end{array}$ & female & 5.43 & 1.243 & .210 \\
\cline { 2 - 5 } & male & 5.07 & 1.602 & .297 \\
\hline $\begin{array}{l}\text { My professors think } \\
\text { that that I should use } \\
\text { Facebook ** }\end{array}$ & female & 6.91 & 1.357 & .233 \\
\cline { 2 - 5 } & male & 3.76 & 2.081 & .387 \\
\hline $\begin{array}{l}\text { My classmates at } \\
\text { university think that I } \\
\text { should use Facebook } \\
\text { ns }\end{array}$ & female & 4.66 & 2.248 & .380 \\
\cline { 2 - 5 } & male & 4.60 & 2.094 & .382 \\
\hline
\end{tabular}

\section{Perceived Trust}

Overall, our survey results did not indicate a high level of trust with people in Facebook, except for the dimension of integrity. First, the belief in the integrity of people in Facebook would convince the members of Facebook that their information would not be used inappropriately and their expected results from social interaction would be fulfilled. Our results showed significant difference in the belief in integrity between male and female students. Female students tended to believe that people in Facebook were honest and reliable; while the male students 
seemed opposite. As one male respondent put, "In fact, when I first set up my profile...I was afraid to add my real personal details and my profile stayed empty for more than three weeks because of my doubt with that website. I was afraid even to add friends to my profile when they send me invitations."

\section{Table 5: Gender Difference in Perceived Trust in Facebook}

(1=Strongly Disagree; 8=Strong Agree)

\begin{tabular}{|c|c|c|c|c|}
\hline \multicolumn{2}{|c|}{$\begin{array}{l}\text { ANOVA results: } * *: \mathrm{p}<.01 \\
*: \mathrm{p}<.05 ; \text { ns: insignificant }\end{array}$} & \multirow{2}{*}{$\frac{\text { Mean }}{5.31}$} & \multirow{2}{*}{\begin{tabular}{|l} 
Std. \\
1.346
\end{tabular}} & \multirow{2}{*}{\begin{tabular}{|l} 
Errol \\
.228
\end{tabular}} \\
\hline Integrity** & female & & & \\
\hline & male & 3.87 & 2.074 & .386 \\
\hline \multirow[t]{2}{*}{ Benevolence* } & female & 2.55 & 2.111 & .361 \\
\hline & male & 3.59 & 1.968 & .419 \\
\hline \multirow[t]{2}{*}{ Ability** } & female & 2.74 & 1.686 & .356 \\
\hline & male & 4.52 & 2.073 & .421 \\
\hline \multirow[t]{2}{*}{ Predictability ${ }^{\mathrm{ns}}$} & female & 3.74 & 2.627 & .322 \\
\hline & male & 4.61 & 2.140 & .470 \\
\hline
\end{tabular}

Second, benevolence deals with the belief that the trusted party actually cares about the trusting party. Our results reported that generally all respondents did not hold a strong belief of benevolence of the members in Facebook. We also found that female students were reported to be more cautious than male students, as indicated by the significant lower rating on benevolence from female students.

Third, the trust dimension of ability is the assessment that the trusted party knows the subject in question and that this knowledge enhances the certainty of the trusting party obtaining its expected outcomes from the relationship. Our results showed that female students had significant lower trust in the others' ability than male students.

Finally, the trust dimension of predictability means the trusted party behaves as expected by the trusting party. Compared to the rating for the trust dimensions of benevolence and ability, the rating for the dimension of predictability are a little bit higher and no significant difference was found between two gender groups.

\section{Perceived Consequences of Facebook Usage}

Based on the focus group discussion, we identified the following four consequences tapping the potential impacts of Facebook in individuality (item1), time management (item2), social relationships (item3) and cultural conflict (item4). In the survey, except for item 3 (Using Facebook keeps me away from real life friends and family), ratings for the other three items were significantly below 4.5. Moreover, the significant gender difference was only reported for item 2 (Using Facebook makes me lose precious time). Particularly, our results showed that using Facebook is not necessarily associated with being unique, which may confirm the popularity of Facebook among the young generation in UAE. Second, due to the multiple pursuits that Facebook can fulfill, using Facebook is not considered as wasting time, which is particularly true among female students. Moreover, all participants were neutral regarding the potential impact of Facebook on physical social life. Finally, participants in our study did not think that using Facebook is against the culture. In stead of following the old generations' opinions about Facebook, the young generation in UAE tries to fit the new technologies and changes into their existing culture system. As one participant put, "His [Imaam] opinion upsets me, and I often thought to myself that he was leader suitable for my grandfather's generation, not mine!”

\section{Table 6: Gender Difference in Perceived Consequences of Facebook Usage (1=Strongly Disagree; 8=Strong Agree)}

\begin{tabular}{|l|l|l|l|l|}
\hline \multicolumn{2}{|l}{$\begin{array}{l}\text { ANOVA results: **: } \mathrm{p}<.01 ; *: \\
\mathrm{p}<.05 ; \text { ns: insignificant }\end{array}$} & Mean & Std. & Error \\
\hline $\begin{array}{l}\text { Using Facebook makes } \\
\text { me different from the } \\
\text { others ns }\end{array}$ & female & 2.94 & 2.127 & .360 \\
\cline { 2 - 5 } & male & 3.94 & 2.220 & .399 \\
\hline $\begin{array}{l}\text { Using Facebook makes } \\
\text { me lose precious } \\
\text { time** }\end{array}$ & female & 1.94 & 1.110 & .188 \\
\cline { 2 - 6 } & male & 3.35 & 2.811 & .505 \\
\hline $\begin{array}{l}\text { Using Facebook keeps } \\
\text { me away from real life } \\
\text { friends and family }\end{array}$ & female & 4.54 & 3.003 & .508 \\
\cline { 2 - 6 } & male & 4.06 & 2.502 & .449 \\
\hline $\begin{array}{l}\text { Using Facebook may } \\
\text { be against our culture, } \\
\text { e.g., putting up other } \\
\text { people's pictures online } \\
\text { ns }\end{array}$ & female & 3.83 & 3.053 & .516 \\
\cline { 2 - 6 } & male & 3.71 & 2.506 & .450 \\
\hline
\end{tabular}

\section{Implications and Future Research}

This research provided an exploratory investigation of Facebook use among university students in UAE with a focus on gender differences. Seventy university students participated in the survey. Before we draw any conclusion, we would like to highlight some limitation of this study that should be considered in externalizing the conclusions to general population. Given the limited exposure, our sample size was small, compared to the population that we tried to study. With specific institutional design, i.e., gender segregation, the surveyed university, compared to the other mixed-gender institutions, attracts many students who are relatively more conservative and more subject to the traditional 
social norms. So our results may reflect more about the Internet usage and its impacts among conservative adolescents in UAE.

Despite the above limitations, our results contribute to the existing literature that is dominant with western evidence by providing the preliminary understanding about the Facebook usage among the young generation in the Arabic region and by revealing significant differences between male and female students. The results of this study suggest further work is warranted to examine the following issues. First, with social networking sites increasingly integrated into young people' daily life, it will be important to examine the impact of such sites on the young's development. Compared to their parental generation, the young generation in UAE has more channels for social interaction, information activities and identity experiment. Particularly, Facebook seems more important for female students in UAE to extend their social network, get information, and experiment different identities. In this study, we identified a wide range of activities with Facebook and also found the female students were reported to be significantly more active than male students. However we only tapped the issue about identity development by indicating their self-perception in Facebook. Particularly the response from the female students showed great difference from the stereotype, e.g., conservative, as requested by traditional culture. In stead the female students, similar to their counterpart, were ready to welcome new friends and new ideas. As one student commented after the survey, "Facebook makes me more open to different perspectives", we expect social networking sites such as Facebook may play an important role in transforming the young generation in Arab world. Second, as one important indicator of local culture, gender role should be considered in the future research on IT adoption/usage in Arabic world. Our results, despite the descriptive nature, have revealed very interesting and significant gender differences. It would be interesting and promising to examine the moderating role of gender in influencing users' behavior in social networking sites.

\section{References}

[1] Boyd, D. and Ellison, N.B. Social network sites, Journal of Computer-Mediated Communication, 13, 2007, pp. 210-230.

[2] Pempek, T.A., Yermolayeva, Y.A., and Calvert, S.L. College students' social networking experiences on Facebook, Journal of Applied Developmental Psychology, 2009.

[3] Ayed, H.A. The Influence of Internet in the Political Culture (A Field Study), Journal of Social Sciences, 1(3), 2005, pp. 128-135.

[4] Solberg, C.A., Culture and industrial buyer behavior: The Arab experience, in The 18th IMP
Conference. 2002: Dijon, France.

[5] Pinsonneault, A. and Heppel, N. Anonymity in Group Support Systems Research: A New Conceptualization, Measure, and Contingency Framework, Journal of Management Information Systems, 14(3), 1998, pp. 89-108.

[6] Smith, M. and Kollock, P., eds. Communities in Cyberspace. 1999, Routledge: London.

[7] DiMaggio, P., Hargittai, E., Celeste, C., and Shafer, S., Digital inequality: From unequal access to differentiated use, in Social Inequality, Neckerman, K., Editor. 2004, Russell Sage Foundation: New York. p. 355-400.

[8] Hargittai, E. and Shafer, S. Differences in actual and perceived online skills: The role of gender, Social Science Quarterly, 87(2), 2006, pp. 432-448.

[9] Venkatesh, V. and Morris, M.G. Why Don't Men Ever Stop to Ask for Directions? Gender, Social Influence, and Their Role in Technology Acceptance and Usage Behavior, MIS Quarterly, 24(1), 2000, pp. 115-139.

[10] Gefen, D. and Straub, D.W. Gender Differences in Perception and Adoption of E-Mail: An Extension to the Technology Acceptance Model, MIS Quarterly, 21(4), 1997, pp. 389-400.

[11] Anderson, J.W. and Eickelman, D.F. Media convergence and ITS consequences, Middle East Insight, March-April, 1999, pp. 59-61.

[12] Erikson, E.H. Young man Luther. 1958, New York: Norton.

[13] Subrahmanyam, K., Smahel, D., and Greenfield, P. Connecting Developmental Constructions to the Internet: Identity Presentation and Sexual Exploration in Online Teen Chat Rooms, Developmental Psychology, 42(3), 2006, pp. 395-406.

[14] Fishbein, M. and Ajzen, I. Belief, Attitude, Intention and Behavior: An Introduction to Theory and Research. 1975, MA: Addison-Wesley Publishing Company, Reading.

[15] Bagozzi, R.B. and Dholakia, U.M. Intentional Social Action in Virtual Communities, Journal of Interactive Marketing, 16(2), 2002, pp. 2-79.

[16] Hogg, M.A. and Abrams, D. Social Identifications: A Social Psychology of Intergroup Relations and Group Processes. 1988, London: Routledge.

[17] Gefen, D. and Straub, D.W. Consumer Trust in B2C e-Commerce and the Importance of Social Presence: Experiments in e-Products and e-Services, Omega, 32(6), 2004, pp. 407-424.

[18] Jarvenpaa, S.L. and Tractinsky, N. Consumer Trust in an Internet Store: A Cross-cultural Validation, Journal of Computer-Mediated Communication 5(2), 1999, pp. 1-35.

[19] Gefen, D., Lessons Learnt from the Successful Adoption of an ERP: The Central Role of Trust, in Recent Developments and Applications in Decision Making, Zanakis, S.D., G. and Zopounidis, C., Editors. 2000, Kluwer Academic.

[20] Tung, L.L., Tan, P.L.J., Chia, P.J.T., Koh, Y.L., and Yeo, H.L. An empirical investigation of virtual communities and trust. in Twenty-Second International Conference on Information Systems. 2001. 
[21] Pavlou, P.A. and Gefen, D. Building Effective Online Marketplaces with Institution-based Trust. in Twenty Third International Conference on Information Systems. 2002.

[22] McKnight, D.H., Choudhury, V., and Kacmar, C. Developing and Validating Trust Measures for e-Commerce: An Integrative Typology, Information Systems Research, 13(3), 2002, pp. 334-359.

[23] Dwyer, C., Hiltz, S.R., and Passerini, K. Trust and Privacy Concern within Social Networking Sites: A Comparison of Facebook and MySpace. in the $13^{\text {th }}$ Americas Conference on Information Systems. 2007. Keystone, Colorado, USA.

\section{Endnote:}

ihttp://www.facebook.com/press/info.php?statistics

iii http://www.internetworldstats.com/me/ae.htm

${ }^{\text {iv }}$ http://hdrstats.undp.org/2008/countries/country_fact sheets/cty_fs_ARE.html

vhttp://www.outsidethebeltway.com/archives/saudi woman_killed_for_chatting_on_facebook_/
[24] Triandis, C.H. Values, Attitudes and Interpersonal Behavior. in Nebraska Symposium on Motivation, 1979: Beliefs, Attitudes and Values. 1980. Lincoln, NE: University of Nebraska Press.

[25] Gefen, D. and Straub, D. Managing User Trust in B2C E-services, E-Service Journal, 2(2), 2003, pp. 7-24.

[26] Limayem, M., Khalifa, M., and Frini, A. What Makes Consumers Buy from Internet? A Longitudinal Study of Online Shopping, IEEE Transactions on Systems, Man and Cybernetics---Part A: Systems and Humans, 30(4), 2000, pp. 421-432. 